4. Durward A, Skellett S, Mayer A, Taylor D, Tibby SM, Murdoch IA (2001) The value of chloride: sodium ratio in differentiating the aetiology of metabolic acidosis. Intensive Care Med 27:828-835

5. Jentsch TJ, Friedrich T, Schriever A, Yamada H (1999) The CLC chloride channel family. Plügers Arch 437: 783-795

\section{Multiple autoantibodies as predictors of Type 1 diabetes in a general population}

To the Editor: Autoantibodies have been widely used to predict the development of Type 1 diabetes [1]. Most studies have been carried out on first-degree relatives of Type 1 diabetic patients $[2,3,4]$ who are at a 10 to 15 -fold higher risk of developing the disease than people in the general population. However, approximately $85 \%$ of all patients who develop Type 1 diabetes do not have an affected family member.

To evaluate the predictive value of autoantibodies in a general population, we screened 9698 Florida school children, who were between 5 and 18 years of age, for islet-cell autoantibodies (ICA). Informed consent was obtained from all subjects under a protocol approved by the institutional review board at the University of Florida. We followed 3854 of these children for 6 to 12 years for the subsequent development of Type 1 diabetes.

DOI 10.1007/s00125-003-1123-7

Received: 3 February 2003 / Revised: 3 February 2003

Published online: 11 June 2003

C) Springer-Verlag 2003
6. Kitabchi AE, Umpierrez GE, Murphy MB et al. (2003) Hyperglycemic Crisis in Patients With Diabetes Mellitus. DiabetesCare 26:S109-S117

Corresponding author: Dr. B. Schneeweiss, Medical Department, Landeskrankenhaus, Kirchdorf a.d. Krems, Austria E-mail: bruno.schneeweiss@univie.ac.at
At the initial screening, 55 children were ICA positive. These children were then tested for autoantibodies to insulin, GAD, IA-2 and IA-2 $\beta$. Of the 55 children positive for ICA 13 also had antibodies to insulin, 18 to GAD, 13 to IA-2 and 8 to IA-2 $\beta$ (Fig. 1). Of the 55 ICA-positive children, 11 progressed to Type 1 diabetes. Of these 11 ICA-positive children, 6 had autoantibodies to insulin, 10 to GAD, 9 to IA-2 and 7 to IA-2 $\beta$. During the course of the study, only one ICA-negative child developed Type 1 diabetes.

Table 1 shows the autoantibody profiles of the 11 ICA-positive children who developed Type 1 diabetes. All had multiple autoantibodies at the initial screening. Clinical disease developed 3 months to 10 years later.

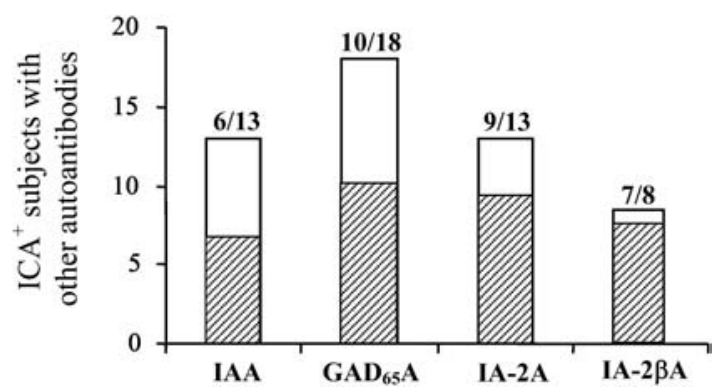

Fig. 1. Autoantibodies in 55 ICA-positive subjects. Shaded areas show number of subjects who progressed to Type 1 diabetes in the presence of each of the autoantibodies

Table 1. Autoantibody profile of children progressing to Type 1 diabetes

\begin{tabular}{|c|c|c|c|c|c|c|c|c|}
\hline \multirow[t]{2}{*}{ Subjects } & \multirow{2}{*}{$\begin{array}{l}\text { Age } \\
\text { (years/months) }^{a}\end{array}$} & \multirow[t]{2}{*}{ Sex } & \multicolumn{5}{|c|}{ Autoantibodies } & \multirow{2}{*}{$\begin{array}{l}\text { Time to Onset } \\
\text { of Diabetes } \\
\text { (years/months) }\end{array}$} \\
\hline & & & ICA & $\mathrm{GAD}_{65} \mathrm{~A}$ & IA-2A & $\mathrm{IA}-2 \beta \mathrm{A}$ & IAA & \\
\hline 2 & $7 / 5$ & $\mathrm{M}$ & + & - & + & + & + & $4 / 3$ \\
\hline 3 & $7 / 9$ & $\mathrm{M}$ & + & + & + & + & - & $1 / 2$ \\
\hline 4 & 10 & $\mathrm{~F}$ & + & + & + & + & + & $3 / 6$ \\
\hline 7 & $7 / 9$ & $\mathrm{M}$ & + & + & + & + & + & $6 / 2$ \\
\hline 8 & $9 / 5$ & $\mathrm{~F}$ & + & + & + & + & + & $0 / 3$ \\
\hline 9 & 7 & $\mathrm{~F}$ & + & + & - & - & - & $6 / 8$ \\
\hline 10 & $8 / 4$ & $\mathrm{~F}$ & + & + & + & - & + & $2 / 0$ \\
\hline $11^{b}$ & $9 / 8$ & $\mathrm{~F}$ & + & + & + & + & + & $10 / 1$ \\
\hline
\end{tabular}

a Age when samples were collected

${ }^{\mathrm{b}}$ Initially autoantibody negative, but became autoantibody positive 3 years later 
Of the 44 ICA-positive children who did not progress to diabetes, 36 had only ICA and none of the other autoantibodies. These children showed normal first-phase insulin release curves as evaluated by intravenous glucose tolerance tests. The remaining 8 ICA-positive children had at least one other autoantibody and showed abnormal first phase insulin release curves suggesting that they were at increased risk of eventually developing Type 1 diabetes.

Taken together with other reports $[5,6,7,8]$, our study shows that with ICA alone, the risk of developing Type 1 diabetes is low, whereas with more than one autoantibody the risk of developing Type 1 diabetes in a general school population is high. These findings on 3854 school children add further support to the concept that multiple autoantibodies are good predictive markers for Type 1 diabetes not only in first degree relatives, but also in a general population.

N. K. Maclaren, M. S. Lan, D. Schatz, J. Malone, A. L. Notkins, J. Krischer

National Institute of Dental and Craniofacial Research, National Institutes of Health, Bethesda, USA

\section{References}

1. Notkins AL, Lernmark A (2001) Autoimmune type 1 diabetes: resolved and unresolved issues. J Clin Invest 108:1247-1252

2. Bingley PJ, Bonifacio E, Williams AJ, Genovese S, Bottazzo GF, Gale EA (1997) Prediction of IDDM in the general population: strategies based on combinations of autoantibody markers. Diabetes 46:1701-1710
3. Kulmala P, Savola K, Peterson JS et al. (1998) Prediction of insulin-dependent diabetes mellitus in siblings of children with diabetes. A population-based study. The Childhood Diabetes in Finland Study Group. J Clin Invest 101:323336

4. Maclaren N, Lan M, Coutant R et al. (1999) Only multiple autoantibodies to islet cells (ICA), insulin, GAD65, IA-2 and IA-2beta predict immune-mediated (type 1) diabetes in relatives. J Autoimmun 12:279-287

5. Samuelsson U, Sundkvist G, Borg H, Fernlund P, Ludvigsson J (2001) Islet autoantibodies in the prediction of diabetes in school children. Diabetes Res Clin Pract 51:51-57

6. LaGasse JM, Brantley MS, Leech NJ et al. (2002) Successful prospective prediction of type 1 diabetes in schoolchildren through multiple defined autoantibodies: an 8-year follow-up of the Washington State Diabetes Prediction Study. Diabetes Care 25:505-511

7. Kimpimaki T, Kulmala P, Savola K et al. (2002) Natural history of beta-cell autoimmunity in young children with increased genetic susceptibility to type 1 diabetes recruited from the general population. J Clin Endocrinol Metab 87:4572-4579

8. Schlosser M, Strebelow M, Wassmuth R et al. (2002) The Karlsburg type 1 diabetes risk study of a normal schoolchild population: association of beta-cell autoantibodies and human leukocyte antigen-DQB1 alleles in antibody-positive individuals. J Clin Endocrinol Metab 87:2254-2261

Corresponding author: Dr. A. L. Notkins, National Institute of Dental and Craniofacial Research, National Institutes of Health, 9000 Rockville Pike. Bldg. 30, Rm. 121, Bethesda, MD 20892, USA

E-mail: anotkins@mail.nih.gov 